to create a particular holidaythemed puzzle for the Sunday magazine. Peter also played an excellent game of golf and, for a time, did serious creative work behind the footlights in community theater.

Both of us writing this remembrance worked with Peter as coauthors. Having him critique or analyses and prose could be slightly deflating, but we always finished with better products when we attended to his concerns. Both of us also knew him as a wonderful friend and colleague. Only the latter writer, however, had Peter as teacher and mentor: a rich experience that convinced him to become a specialist in Latin American politics.

Peter was part Cherokee and his Native American heritage meant a good deal to him. For that reason, he established through the American Indian College Fund a scholarship for students wishing to study political science. Contributions may be sent to the Peter G. Snow Scholarship, c/o Marge, American Indian College Fund, PO Box 19019, NY, NY 10277-0386.

Survivors include a son, Steven (who teaches political science at Wagner College); a daughter-in-law, Cheryl Wheeler; and a newborn granddaughter, Ailie Anne.

Those whose lives Peter touched-family and friends, students and colleagues-will greatly miss this very special man.

Douglas Madsen

University of lowa

Luigi Manzetti

Southern Methodist University

\section{Lloyd M. Wells}

Our colleague of many years, Lloyd Manning Wells, Professor Emeritus of Political Science at the University of Missouri, Columbia, passed away on January 4, 2000, after a lingering illness. He was 80 years old.
Lloyd was born in the small community of Clever, Missouri, in 1919. He was drafted into the Army in June of 1941 and, after attending OCS, was commissioned as a Second Lieutenant with the 1st Armored Division. Lloyd saw action in North Africa, Italy, and Germany. He was awarded the Combat Infantry Badge, the Purple Heart with two oak clusters, and the Bronze Star. He left the Army as a First Lieutenant and enrolled at Southwest Missouri State College, from which he received a B.A. in 1948. He received an M.A. from the University of Missouri in 1950 and a Ph.D. from Princeton University in 1955. While a student at Princeton, Lloyd worked for the Legislative Reference Bureau of the New Jersey State Legislature. He was a member of the Southern Methodist University faculty from 1955 to 1958 and served on the University of Missouri faculty from 1958 until he retired in 1985.

Lloyd's research centered on the Supreme Court and the bureaucracy. He coauthored The Supreme Court and Public Opinion and his articles appeared in Social Science Quarterly and Public Administration Review as well as several anthologies.

We remember him best as a teacher, administrator, and colleague. He taught courses ranging from freshman-level American government to advanced undergraduate courses and graduate seminars in public administration. He received praise for his teaching, for his ability to stimulate thought, and for his gentle sense of humor. He dealt with students in class and individually in a sympathetic and encouraging manner.

At one time or another, he held every administrative position in the department and carried out all assignments with aplomb. As chair from 1967 to 1970 , Lloyd was sensitive to the needs of faculty to exercise their discretion in teaching and research. He was the type of academic administrator who believed that a community of scholars could behave in a collegial and responsible way, and he conducted himself in such a manner as to draw those values out in others.

His consecutive terms as graduate director and chair coincided with a considerable expansion of faculty and graduate students in the department. Lloyd conducted himself as a faculty member, as graduate director, and as department chair with integrity and fairness. He employed his good judgment and mediation skills to help members of departmental committees work their way through potentially divisive problems. Withal, there was his clever wit to enliven meetings.

From our personal perspectives, he performed his greatest service by easing the passage from a smaller to a larger program for young faculty and graduate students orienting themselves to the teaching profession and discipline. His graduate students from that era have continued to refer to Lloyd simply as "the chairman" when they have gotten together in later years.

He is survived by his wife of fifty years, Carolyn, and three grandchildren. A son, Randall, preceded him in death.

Lloyd will be missed by his family, his colleagues, and his students. However, we are content that his was truly a life worth living.

Dean L. Yarwood

University of Missouri, Columbia

David M. Wood

University of Missouri, Columbia 


\section{American Politial Science Association Online}

\section{Have You}
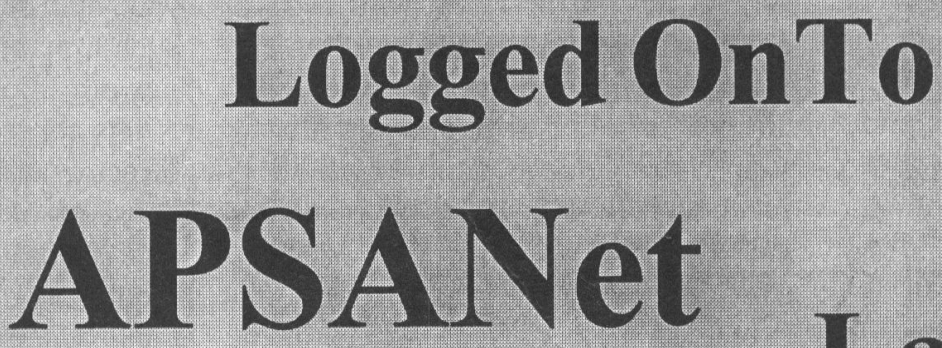

See what the new

Research Support

APSANet

has to

Upcoming

Conferences

offer.

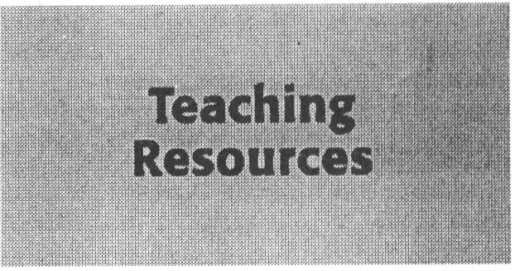

\section{Career \\ Opportunities}

\section{wWw.apsanet.org}

It's a resource. Check it out.

Publications 